\section{Hematological and biochemical aspects of cats naturally infected with feline immunodeficiency virus and feline leukemia}

\author{
Aspectos hematológicos e bioquímicos de gatos naturalmente \\ infectados pelos vírus da imunodeficiência felina e da leucemia \\ felina
}

\author{
Luciana Carvalho Lacerda' ${ }^{\mathbb{D}}$, Aísla Nascimento da Silva² (10, Rebeca Dálety Santos Cruz² (D), \\ Jéssica de Souza Freitas ${ }^{2}$ (D) , Roueda Abou Said ${ }^{3}$ (D) \& Alexandre Dias Munhoz ${ }^{3 *}$ (D) \\ 'Veterinarian, DSc. Programa de Pós-graduação em Ciência Animal (PPGCA), Universidade Estadual de Santa Cruz (UESC), \\ Ilhéus, BA, Brasil \\ Veterinarian, MSc. PPGCA, UESC, Ihéus, BA, Brasil \\ ${ }^{3}$ Veterinarian, DSc. Departamento de Ciências Agrárias e Ambientais, UESC, Ilhéus, BA, Brasil
}

\begin{abstract}
Considering the importance and severity of feline immunodeficiency virus (FIV) and feline leukemia virus (FeLV) infections, information on laboratory abnormalities can determine the prognosis of infected cats. This study aimed to determine the laboratory alterations of domiciled asymptomatics cats naturally infected by FIV and/or FeLV in Northeastern Brazil. Blood samples from 200 cats were evaluated by nested-PCR and commercial immunochromatographic test for diagnosis of these infections. Complete blood count (CBC) and serum biochemistry analyses were performed to evaluate laboratory abnormalities. CBC and biochemical values of cats tested positive for FIV and/or FeLV were tabulated for the presence or absence of changes and analyzed using the chi-square test with Yates correction or Fisher's exact test for each variable, with a confidence interval of 95\%. The total frequency was 6\% (12/200) and 3\% (6/200) for FIV and FeLV, respectively. The presence of hyperbilirubinemia (total, direct, and indirect) was the only change observed in cats positive for FIV compared to FIV-negative controls ( $p<0.05$ ). We believe that laboratory changes compatible with immunosuppressive conditions should be more frequent in FIV/FeLV positive cats that already present clinical signs of the disease.
\end{abstract}

Keywords: bilirubin, retroviruses, FIV, FeLV.

\section{Resumo}

Considerando a importância e a gravidade das infecções pelo vírus da imunodeficiência felina (FIV) e pelo vírus da leucemia felina (FeLV), informações sobre as alterações laboratoriais são determinantes no prognóstico dos pacientes. Objetivou-se com este estudo determinar as alterações laboratoriais de gatos assintomáticos domiciliados, naturalmente infectados pelo FIV e/ou FeLV “do nordeste do" Brasil. Amostras de sangue de 200 gatos foram avaliadas pela técnica de nested-PCR e pelo teste comercial imunocromatográfico para o diagnóstico dessas infecções. Hemograma completo e bioquímica sérica foram realizadas para avaliar as alterações laboratoriais. Os hemogramas e bioquímicos dos animais positivos para FIV e/ou FeLV foram tabulados quanto a presença ou ausência de alterações e analisados através do teste qui-quadrado com correção de Yates ou teste exato de Fisher para cada variável, com intervalo de confiança de 95\%. A frequência total foi de 6\% (12/200) e 3\% (6/200) para FIV e FeLV, respectivamente. A presença de hiperbilirrubinemia (total, direta e indireta) foi a única alteração observada nos gatos positivos para FIV em relação aos animais negativos $(p<0,05)$. Acreditamos que alterações laboratoriais compatíveis com quadros de imunossupressão devam ser mais frequentes em gatos FIV/FeLV positivos que já apresentem sinais clínicos da doença.

Palavras-chave: bilirrubina, retrovírus, FIV, FeLV.

\section{Introduction}

The feline immunodeficiency virus (FIV) and feline leukemia virus (FeLV) are two retroviruses that promote a progressive imbalance in the metabolism and immune system of the affected \section{B] M \\ Brazilian Journal of Veterinary Medicine \\ p-ISSN 0100-2430 \\ e-ISSN 2527-2179 \\ ○}

How to cite: Lacerda, L. C., Silva, A. N., Cruz, R. D. S., Freitas, J. S., Said, R. A., \& Munhoz, A. D. (2O2O). Hematological and biochemical aspects of cats naturally infected with feline immunodeficiency virus and feline leukemia. Brazilian Journal of Veterinary Medicine, 42, e110020. https://doi. org/10.29374/2527-2179.bjvm110020

Financial support: Universidade Estadual de Santa Cruz.

Conflict of interests: No conflict of interests declared concerning the publication of this article.

Received: January 27th, 2020.

Accepted: April 13th, 2020

The study was carried out at Laboratório de Análises Clínicas Veterinárias, Departamento de Ciências Agrárias e Ambientais, Universidade Estadual de Santa Cruz-UESC, Ilhéus, BA, Brasil.

\section{*Correspondence}

Alexandre Dias Munhoz

Departamento de Ciências Agrárias e

Ambientais, Universidade Estadual de Santa

Cruz - UESC

Campus Soane Nazaré de Andrade, Rodovia Jorge Amado, Km 16, Salobrinho

CEP 45662-900 - Ilhéus (BA), Brasil

E-mail:munhoz@uesc.br 
animals (Hosie et al., 2009; Hartmann, 2011; Teixeira et al. 2019). Diagnosis of FIV/FeLV infections is performed by associating the clinical signs presented by the cats to complementary laboratory tests (Teixeira et al., 2007; Little et al., 2020). Diagnosis is necessary for the practice of preventive measures such as early vaccination and the initiation of necessary care in the case of positive animals (Levy et al., 2008; Westman et al., 2016).

Clinical laboratory changes presented by positive FIV/FeLV animals depend on the infection stage (Gleich \& Hartmann, 2009). Animals can present with fever, anorexia, lymphadenopathy, leukemias, and changes in hematological aspects such as anemia, neutropenia, and lymphopenia, which indicates immunosuppression (Collado et al., 2012; Novo et al., 2016; Costa et al., 2017; Cristo et al., 2019). The biochemical findings described are diverse and nonspecific, with reports of increased concentrations of glucose, total protein, urea, and creatinine (Hofmann-Lehmann et al. 1997; Hosie et al., 2009; Poli et al., 2012).

Considering the severity of these infections, information about laboratory changes in positive FIV and FeLV animals can be useful in determining the prognosis of infected felines. This study aimed to determine the laboratory alterations of domiciled cats naturally infected by FIV and/ or FeLV in the microregion of Ilhéus-Itabuna, Bahia, Brazil.

\section{Materials and methods}

\section{Location of the study and sampling design}

Between February 2012 and April 2013, an epidemiological study of analytical cross-sectional

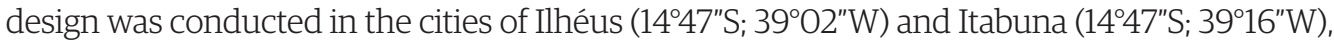
which are within the microregion of Ilhéus-Itabuna, Bahia, Brazil. Through non-probability sampling, 200 cat owners were selected from the records of veterinary clinics in the region. The inclusion criteria were as follows: 1) Asymptomatic cats, i.e., clinical examination did not show any abnormalities suggestive of systemic disease such as vomiting, diarrhea, weight loss, nasal secretion, or neoplasia (Collado et al., 2012); and 2) cats aged 6 months or over. The study was conducted in accordance with the principles of bioethics and animal welfare, under protocol number 011/12 (CEUA/UESC).

\section{Serological tests for FIV and FeLV}

Three milliliters of blood was collected by venous, cephalic, or jugular puncture from each cat, where $1 \mathrm{~mL}$ was reserved for performing the complete blood count (CBC) and extracting DNA, and $2 \mathrm{~mL}$ for analysing the biochemical and serological profiles. The samples were tested for retroviruses using the commercial immunochromatography test: FIV ac/FeLV Ag Test Kit $\left(\right.$ Alere $\left.{ }^{\circledR}\right)$, following the manufacturer's recommendations.

\section{Extraction of genomic DNA and polymerase chain reaction (PCR) for FIV and FeLV}

Genomic DNA was extracted from total blood using a commercial kit (QIAamp DNA Blood Minikit; QiagenTM), following the manufacturer's recommendations. All samples were subjected to nested PCR for detection of FIV and FeLV. The samples that presented negative results were subjected to GAPDH gene amplification in order to check the integrity of DNA and the absence of potential inhibitors. Table 1 presents the primers used for each PCR (FIV, FeLV, and GAPDH).

For amplification of the proviral DNA of FIV, nested PCR with two reactions were set up, each with a final volume of $25 \mu \mathrm{L}$ composed of $10 \mathrm{X}$ buffer, $2.0 \mathrm{mM} \mathrm{MgCl} \mathrm{2}^{\prime}, 0.2 \mathrm{mM}$ of each dNTP, $1 \mu \mathrm{M}$ of each primer, and $1.25 \mathrm{U}$ Taq DNA polymerase. In the first reaction, $5 \mu \mathrm{L}$ DNA of sample DNA was added and then $2 \mu \mathrm{L}$ of the amplification product from this reaction was used in the second reaction. Sterile ultrapure water was used to complete the final reaction volume. The two reactions followed the same amplification protocol: initial denaturation at $95^{\circ} \mathrm{C}$ for $5 \mathrm{~min}$, followed by 30 cycles at $95^{\circ} \mathrm{C}$ for $45 \mathrm{~s}, 58^{\circ} \mathrm{C}$ for $45 \mathrm{~s}$, and $72{ }^{\circ} \mathrm{C}$ for $45 \mathrm{~s}$, and a final extension at $72^{\circ} \mathrm{C}$ for $5 \mathrm{~min}$. The composition of the reactions and amplification protocols was adapted from a previously described report (Hohdatsu et al.,1998).

To assess the proviral DNA of FeLV, nested PCR was performed. Both reactions presented final volumes of $25 \mu \mathrm{L}$, containing $10 \mathrm{X}$ buffer; $2.0 \mathrm{mM} \mathrm{MgCl}_{2} ; 0.2 \mathrm{mM}$ of each dNTP; $0.4 \mu \mathrm{M}$ of each 
Table 1. Primers used in nested-PCR for FIV and FeLV, and GAPDH. Oligonucleotide sequence, gene and amplified product size.

\begin{tabular}{|c|c|c|c|c|}
\hline & Sequence 5'-3' & Region & Product & References \\
\hline \multicolumn{5}{|l|}{ FIV } \\
\hline $\mathrm{A} 2$ & AAT ATG ACT GTA TCT ACT GC & \multirow{2}{*}{ gag } & \multirow{4}{*}{ 329pb } & \multirow{2}{*}{ Hohdatsu et al. (1998) } \\
\hline $\mathrm{S} 2$ & TTT TCT TCT AGA GTA CTT TCT GG & & & \\
\hline NS & TAT TCA AAC AGT AAA TGG AG & \multirow{2}{*}{ gag } & & \multirow{2}{*}{ Hohdatsu et al. (1998) } \\
\hline NA & CTG CTT GTT GTT CTT GAG TT & & & \\
\hline \multicolumn{5}{|l|}{ FeLV } \\
\hline $\mathrm{U} 3-\mathrm{F}$ & ACA GCA GAA GTT TCA AGG CC & \multirow{2}{*}{$\mathrm{U} 3 / g a g$} & & \multirow{2}{*}{$\begin{array}{c}\text { Miyazawa \& Jarrett } \\
\text { (1997) }\end{array}$} \\
\hline G-R & GAC CAG TGA TCA AGG GTG AG & & & \\
\hline $\mathrm{U} 3-\mathrm{F}(2)$ & GCT CCC CAG TTG ACC AGA GT & \multirow{2}{*}{$\mathrm{U} 3 / g a g$} & \multirow{2}{*}{ 601pb } & \multirow{2}{*}{$\begin{array}{c}\text { Miyazawa \& Jarrett } \\
\text { (1997) }\end{array}$} \\
\hline $\mathrm{G}-\mathrm{R}(2)$ & GCT TCG GTA CCA AAC CGA AA & & & \\
\hline \multicolumn{5}{|l|}{ GAPDH } \\
\hline GAPDH F & CCT TCA TTG ACC TCA ACT ACAT & & \multirow{2}{*}{ 400pb } & \multirow{2}{*}{$\begin{array}{l}\text { Birkenheuer et al. } \\
\text { (2003) }\end{array}$} \\
\hline GAPDH R & CCA AAG TTG TCA TGG ATG ACC & & & \\
\hline
\end{tabular}

primer; and 1.25 U Taq DNA polymerase. In the first reaction, $5 \mu \mathrm{L}$ of the sample DNA was added, and $2 \mu \mathrm{L}$ of the amplification product from this reaction was used in the second reaction. Sterile ultrapure water was used to complete the final reaction volumes. The amplification protocol consisted of initial denaturation at $94^{\circ} \mathrm{C}$ for $7 \mathrm{~min}$, followed by 33 cycles at $94^{\circ} \mathrm{C}$ for $55 \mathrm{~s}, 55.3^{\circ} \mathrm{C}$ for $55 \mathrm{~s}$ in the first reaction and $59.5^{\circ} \mathrm{C}$ for $55 \mathrm{~s}$ in the second reaction, $72{ }^{\circ} \mathrm{C}$ for $70 \mathrm{~s}$, and a final extension at $72^{\circ} \mathrm{C}$ for $7 \mathrm{~min}$. The composition of the reactions and amplification protocols was adapted from a previosuly described report (Miyazawa \& Jarrett, 1997).

For GAPDH gene amplification, final reaction volume of $25 \mu \mathrm{L}$ was set up comprising of $10 \mathrm{X}$ buffer, $2.0 \mathrm{mM} \mathrm{MgCl}, 0.2 \mathrm{mM}$ of each dNTP, $1.0 \mu \mathrm{M}$ of each primer, $1.25 \mathrm{U}$ Taq DNA polymerase, and $5 \mu \mathrm{L}$ of sample DNA. The amplification protocol consisted of initial denaturation at $95^{\circ} \mathrm{C}$ for $5 \mathrm{~min}$, followed by 40 cycles at $94^{\circ} \mathrm{C}$ for $30 \mathrm{~s}, 52^{\circ} \mathrm{C}$ for $1 \mathrm{~min}$, and $72{ }^{\circ} \mathrm{C}$ for $1 \mathrm{~min}$, and a final extension at $72^{\circ} \mathrm{C}$ for $5 \mathrm{~min}$. The composition of the reactions and amplification protocols was adapted from a previously described report (Birkenheuer et al., 2003).

\section{Hematological and biochemical analysis}

The CBC was performed on an automatic counter (ABX VET, Horiba ${ }^{\mathrm{TM}}$, Montpellier, France). Total plasma protein concentrations were determined using a manual clinical refractometer, and for specific leukometry blood smears stained with Giemsa stain (Merck S/A, Rio de Janeiro, Rio de Janeiro, Brazil) were performed and examined under an optical microscope at 100X magnification. The reference values used were according to the report by Jain (1993).

To determine the serum activity of the enzymes, levels of alanine aminotransferase (ALT), aspartate aminotransferase (AST), gamma glutamyltranspeptidase (GGT), and concentration of urea, creatinine, and bilirubin (total, direct and indirect) were assessed by the commercial kit Labtest $^{\circledR}$ (Labtest, Lagoa Santa, Minas Gerais, Brazil) in the Bioplus $2000^{\circledR}$ biochemical analyzer (Bioplus Ltd., Barueri, São Paulo, Brazil) and the reference values were based on Kaneko et al. (1997).

\section{Statistical analysis}

To perform the bivariate analysis, the results of hematologicaland biochemical analyses of cats positive and negative for FIV or FeLV (outcome variables) were categorized into the following variables: has anemia (yes or no); leukopenia (yes or no); neutropenia (yes or no); lymphopenia (yes or no); thrombocytopenia (yes or no); hyperproteinemia (yes or no); increased ALT (yes or no); increased AST (yes or no); increased GGT (yes or no); increased urea (yes or no); increased creatinine (yes or no); increase in total bilirubin (yes or no); increase in indirect bilirubin (yes or 
no), and increase in indirect bilirubin (yes or no). Frequency distribution was determined using the chi-square test with Yates correction or Fisher's exact test. The chance of occurrence(OR) of the bivariate analysis was calculated using association measures and a 95\% confidence interval.

\section{Results}

Of the 200 cats evaluated in the present study using nested-PCR and commercial immunochromatographic test, 6\% (12/200) and 3\% (6/200) tested positive for FIV and FeLV, respectively. No cat was positive for both viruses.

Hematological and biochemical results were analyzed for possible associations with FIV positive status (Table 2). A greater proportion of FIV positive cats showed an increase in the concentration of bilirubins (total, direct, and indirect) in relation to FIV negative cats $(\mathrm{p}<0.05)$ and showed a tendency toward hyperproteinemia.

Table 2. Contingency tables for hematological and biochemical variables categorized with FIV status.

\begin{tabular}{|c|c|c|c|c|c|c|}
\hline \multirow{3}{*}{ VARIABLES } & \multicolumn{4}{|c|}{ FIV } & \multicolumn{2}{|c|}{ Odds ration } \\
\hline & \multicolumn{2}{|c|}{ POSITIVES } & \multicolumn{2}{|c|}{ NEGATIVES } & \multirow{2}{*}{ CI 95\% } & \multirow{2}{*}{$p$} \\
\hline & $\mathbf{N}$ & $\%$ & $\mathbf{N}$ & $\%$ & & \\
\hline \multicolumn{7}{|l|}{ ANEMIA } \\
\hline YES (Packed cell volume < 24\%) & 3 & $25.0 \%$ & 20 & $10.7 \%$ & \multirow{2}{*}{$2.8(0.6-11.2)$} & \multirow{2}{*}{0.14} \\
\hline NO (Packed cell volume $\geq 24 \%$ ) & 9 & $75.0 \%$ & 168 & $89.3 \%$ & & \\
\hline \multicolumn{7}{|l|}{ LEUKOPENIA } \\
\hline YES (White blood cell < 5.500/mm3) & 0 & $0 \%$ & 12 & $6.4 \%$ & \multirow{2}{*}{$*$} & \multirow{2}{*}{0.46} \\
\hline NO (White blood cell $\geq 5.500 / \mathrm{mm} 3$ ) & 12 & $100 \%$ & 176 & $93.6 \%$ & & \\
\hline \multicolumn{7}{|l|}{ NEUTROPENIA } \\
\hline YES (Neutrophils < 2.500/mm3) & $\mathrm{O}$ & $0 \%$ & 4 & $2.0 \%$ & \multirow{2}{*}{$*$} & \multirow{2}{*}{0.77} \\
\hline NO (Neutrophils $\geq 2.500 / \mathrm{mm} 3$ ) & 12 & $100 \%$ & 184 & $97.8 \%$ & & \\
\hline \multicolumn{7}{|l|}{ LYMPHOPENIA } \\
\hline YES (Lymphocytes < 1.500/mm3) & 3 & $25.0 \%$ & 25 & $13.3 \%$ & \multirow{2}{*}{$2.1(0.5-8.5)$} & \multirow{2}{*}{0.22} \\
\hline NO (Lymphocytes $\geq 1.500 / \mathrm{mm} 3$ ) & 9 & $75.0 \%$ & 163 & $86.7 \%$ & & \\
\hline \multicolumn{7}{|l|}{ THROMBOCYTOPENIA } \\
\hline YES (Platelets < 200.000/mm3) & 5 & $41.7 \%$ & 104 & $55.3 \%$ & \multirow{2}{*}{$0.5(0.1-1.8)$} & \multirow{2}{*}{0.26} \\
\hline NO (Platelets $\geq 200.000 / \mathrm{mm} 3$ ) & 7 & $58.3 \%$ & 84 & $44.7 \%$ & & \\
\hline \multicolumn{7}{|l|}{ HYPERPROTEINEMIA } \\
\hline YES (Total Protein >7,8g/dl) & 5 & $41.7 \%$ & 32 & $17.1 \%$ & \multirow{2}{*}{$3.4(1-11.6)$} & \multirow{2}{*}{0.08} \\
\hline NO (Total Protein $\leq 7,8 \mathrm{~g} / \mathrm{dl}$ ) & 7 & $58.3 \%$ & 156 & $82.9 \%$ & & \\
\hline \multicolumn{7}{|l|}{ INCREASED ALT } \\
\hline YES (ALT > 83 U/L) & 1 & $8.3 \%$ & 8 & $4.3 \%$ & \multirow{2}{*}{$2(0.2-17.8)$} & \multirow{2}{*}{0.43} \\
\hline $\mathrm{NO}(\mathrm{ALT} \leq 83 \mathrm{U} / \mathrm{L})$ & 11 & $95.7 \%$ & 180 & $95.7 \%$ & & \\
\hline \multicolumn{7}{|l|}{ INCREASED AST } \\
\hline YES (AST > $43 \mathrm{U} / \mathrm{L})$ & 4 & $33.3 \%$ & 56 & $29.8 \%$ & \multirow{2}{*}{$1,1(0.3-4)$} & \multirow{2}{*}{0.5} \\
\hline 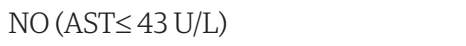 & 8 & $66.7 \%$ & 132 & $70.2 \%$ & & \\
\hline INCREASED GGT & & & & & & \\
\hline YES (GGT > 5,1 U/L) & 0 & $0.0 \%$ & 15 & $8.0 \%$ & $*$ & סح> \\
\hline $\mathrm{NO}(\mathrm{GGT} \leq 5,1 \mathrm{U} / \mathrm{L})$ & 12 & $100 \%$ & 173 & $92.0 \%$ & & .J. \\
\hline
\end{tabular}

*Indeterminate. 
Table 2. Continued...

\begin{tabular}{|c|c|c|c|c|c|c|}
\hline \multirow{3}{*}{ VARIABLES } & \multicolumn{4}{|c|}{ FIV } & \multicolumn{2}{|c|}{ Odds ration } \\
\hline & \multicolumn{2}{|c|}{ POSITIVES } & \multicolumn{2}{|c|}{ NEGATIVES } & \multirow{2}{*}{ CI 95\% } & \multirow{2}{*}{$p$} \\
\hline & $\mathbf{N}$ & $\%$ & $\mathbf{N}$ & $\%$ & & \\
\hline \multicolumn{7}{|l|}{ INCREASED UREA } \\
\hline YES (Urea > 64 mg/dl) & 0 & $0.0 \%$ & 4 & $2.1 \%$ & \multirow{2}{*}{ * } & \multirow{2}{*}{0.77} \\
\hline NO (Urea $\leq 64$ mg/dl) & 12 & $100 \%$ & 184 & $97.9 \%$ & & \\
\hline \multicolumn{7}{|l|}{ INCREASED CREATININE } \\
\hline YES (Creatinine > 1,8 mg/dl) & 2 & $16.7 \%$ & 42 & $22.3 \%$ & \multirow{2}{*}{$0.69(0.1-3.2)$} & \multirow{2}{*}{0.48} \\
\hline $\mathrm{NO}$ (Creatinine $\leq 1,8 \mathrm{mg} / \mathrm{dl})$ & 10 & $83.3 \%$ & 146 & $77.7 \%$ & & \\
\hline \multicolumn{7}{|l|}{ INCREASED IN TOTAL BILIRUBIN } \\
\hline YES (Total Bilirubin > 0.6 mg/dl) & 8 & $66.6 \%$ & 60 & $32.0 \%$ & \multirow{2}{*}{$4.2(1.2-14.7)$} & \multirow{2}{*}{0.01} \\
\hline NO (Total Bilirubin $\leq 0.6$ mg/dl) & 4 & $33.4 \%$ & 128 & $68.0 \%$ & & \\
\hline \multicolumn{7}{|l|}{ INCREASED DIRECT BILIRUBIN } \\
\hline YES (Direct Bilirubin> 0.3 mg/dl) & 2 & $16.7 \%$ & 2 & $1.1 \%$ & \multirow{2}{*}{$18,6(2.3-146)$} & \multirow{2}{*}{0.01} \\
\hline NO (Direct Bilirubin $\leq 0.3$ mg/dl) & 10 & $83.3 \%$ & 186 & $98.9 \%$ & & \\
\hline \multicolumn{7}{|l|}{ INCREASED INDIRECT BILIRUBIN } \\
\hline YES (Indirect Bilirubin > 0.5 mg/dl) & 9 & $75.0 \%$ & 68 & $36.2 \%$ & \multirow{2}{*}{$5.2(1.3-20.2)$} & \multirow{2}{*}{0.009} \\
\hline NO (Indirect Bilirubin $\leq 0.5$ mg/dl) & 3 & $25.0 \%$ & 120 & $63.8 \%$ & & \\
\hline
\end{tabular}

*Indeterminate

Due to the low number of FeLV positive cats, it was not possible to perform a statistical analysis, only a descriptive analysis. Of the six positive animals, none had anemia, leukopenia, neutropenia, lymphopenia, and three (50\%) had thrombocytopenia. Among biochemical parameters, two cats showed an increase in serum ALT (17.6\%) and AST (17.6\%), respectively, whereas none of the cats presented hyperproteinemia and increased concentrations of urea and creatinine. Furthermore, two cats presented an increase in total and indirect bilirubin concentrations (33.3\%).

\section{Discussion}

To the best of our knowledge, this is the first study in Northeastern Brazil to assess hematological and biochemical parameters in cats naturally infected with FIV/FeLV. These retroviruses are associated with a variety of laboratory findings related to decreased animal immunity (Gleich \& Hartmann, 2009; Teixeira et al., 2019).

The presence of anemic conditions has already been well described in FIV positive cats due to the inflammatory process triggered by the virus, whichblocks the uptake of iron (Shelton et al. 1990) as well as in cats infected with FeLV-C subtype, leading to secondary infections and neoplastic cell formation (Gleich \& Hartmann, 2009; Hartmann, 2011; Cristo et al., 2019). In our study, we observed a low risk for the development of hematological changes for both viruses. We believe that this is due to the stage of infection (subclinical) presented by these animals at the time of collection. Collado et al. (2012) observed that FeLV positive cats with clinical signs were more likely to have lower total red blood cell counts than those without signs.

There was no statistical association between the leukogram results and retroviral infection, reinforcing the hypothesis of the absence of bone marrow involvement. Changes in the total leukocyte count are related to the reduction in the number of circulating neutrophils, mainly in the acute phase of infections and later in the immunosuppression phase, due to insufficient myelopoiesis (Shelton et al., 1990; Costa et al., 2017; Turinelli \& Gavazza, 2018). Lymphopenia is related to the onset of immunosuppression, with a decrease in the number of CD4 and CD8 cells (Hofmann-Lehmann et al., 1997; Novo et al., 2016; Little et al., 2020). 
Regarding biochemical changes, we observed a tendency towards hyperproteinemia in FIV positive cats. Hartmann (2011) and Liem et al. (2013) reported an increase in plasma globulins in cats as a result of the polyclonal expansion of Blymphocytes in response to FIV. Hyperbilirubinemia is associated with the presence of FIV and has already been described in cases of immune-mediated hemolytic anemia in cats facing infectious diseases, including those caused by retroviruses (Kohn et al., 2006; Tasker et al., 2010). However, in the present study, the occurrence of hemolysis in an immune-mediated manner did not cause anemia in cats.

The results of the present study suggest that FIV/FeLV positive cats without clinical signs selected for cross-sectional studiesmay not initially show laboratory alterations compatible with immunosuppression. We believe that the hyperbilirubinemia presented by FIV positive cats should be evaluated with caution, and further studies are needed to assess the role of FIV in animal metabolism.

\section{Acknowledgements}

We would like to thank all the tutors in the cities of Ilhéus and Itabuna for allowing the samples to be collected. We also thank Prof. João Pessoa Araújo Júnior, Department of Microbiology and Immunology, Institute of Biosciences of Botucatu, UNESP, Botucatu, São Paulo, Brazil, for providing positive controls for FIV and FeLV. This study was funded by the State University of Santa Cruz.

\section{References}

Birkenheuer, A. J., Levy, M. G., \& Breitschwerdt, E. B. (2003). Development and evaluation of a semi nested PCR for detection and differentiation of Babesia gibsoni (Asian Genotype) and B. canis DNA in canine blood samples. Journal of Clinical Microbiology, 41(9), 4172-4177. http://dx.doi.org/10.1128/JCM.41.9.4172-4177.2003. PMid:12958243.

Collado, V. M., Domenech, A., Miró, G., Martin, S., Escolar, E., \& Gomez-Lucia, E. (2012). Epidemiological aspects and clinicopathological findings in cats naturally infected with Feline Leukemia Virus (FeLV) and/or Feline Immunodeficiency Virus (FIV). Open Journal of Veterinary Medicine, 2(01), 13-20. http://dx.doi.org/10.4236/ ojvm.2012.21003.

Costa, F. V. S., Valle, S. F., Machado, G., Corbellini, L. G., Coelho, E. M., Rosa, R. B., \& Gonzalez, F. H. D. (2017). Hematological findings and factors associated with feline leukemia virus (FeLV) and feline immunodeficiency virus (FIV) positivity in cats from southern Brazil. Pesquisa Veterinária Brasileira, 37(12), 1531-1536. http:// dx.doi.org/10.1590/s0100-736x2017001200028.

Cristo, T. G., Biezus, G., Noronha, L. F., Gaspar, T., Dal Pont, T. P., Withoeft, J. A., Furlan, L. V., Costa, L. S., Traverso, S. D., \& Casagrande, R. A. (2019). Feline leukaemia virus associated with leukaemia in cats in Santa Catarina, Brazil. Journal of Comparative Pathology, 170,10-21. http://dx.doi.org/10.1016/j.jcpa.2019.05.002. PMid:31375152.

Gleich, S., \& Hartmann, K. (2009). Hematology and serum biochemistry of feline Immunodeficiency virusinfected and feline leukemia virus-infected cats. Journal of Veterinary Internal Medicine, 23(3), 552-558. http:// dx.doi.org/10.1111/j.1939-1676.2009.0303.x. PMid:19645840.

Hartmann, K. (2011). Clinical aspects of feline immunodeficiency and feline leukemia virus infection. Veterinary Immunology and Immunopathology, 143(3-4), 190-201. http://dx.doi.org/10.1016/j.vetimm.2011.06.003. PMid:21807418.

Hofmann-Lehmann, R., Holznagel, E., Ossent, P., \& Lutz, H. (1997). Parameters of disease progression in longterm experimental feline retrovirus (feline immunodeficiency virus and feline leukemia virus) infections: hematology, clinical chemistry, and lymphocyte subsets. Clinical and Diagnostic Laboratory Immunology, 4(1), 33-42. http://dx.doi.org/10.1128/CDLI.4.1.33-42.1997. PMid:9008278.

Hohdatsu, T., Motokawa, K., Usami, M., Amioka, M., Okada, S., \& Koyama, H. (1998). Genetic subtyping and epidemiological study of feline immunodeficiency virus by nested polymerase chain reaction-restriction fragment length polymorphism analysis of the gag gene. Journal of Virological Methods, 70(1), 107-111. http:// dx.doi.org/10.1016/S0166-0934(97)00167-5. PMid:9506819.

Hosie, M. J., Addie, D., Belak, S., Boucraut-Baralon, C., Egberink, H., Frymus, T., Gruffydd-Jones, T., Hartmann, K., Loret, A., Lutz, H., Marsilio, F., Pennisi, M. G., Radford, A. D., Thiry, E., Truyen, U., \& Horzinek, M. C. (2009). Feline immunodeficiency: ABCD guidelines on prevention and management. Journal of Feline Medicine and Surgery, 11(7), 575-584. http://dx.doi.org/10.1016/j.jfms.2009.05.006. PMid:19481037.

Jain, N. C. (1993). Examination of the blood and bone marrow. In N. C. Jain (Ed.), Essentials of veterinary hematology (5th ed., pp. 6-20). Philadelphia: Lea \& Febiger.

Kaneko, J. J., Harvey, J. W., \& Bruss, M. L. (1997). Clinical biochemistry of domestic animals. San Diego: Academic Press.

Kohn, B., Weingart, C., Eckmann, V., Ottenjann, M., \& Leibold, W. (2006). Primary immune-mediated hemolytic anemia in 19 cats: diagnosis, therapy, and outcome (1998-2004). Journal of Veterinary Internal Medicine, 20(1), 159-166. PMid:16496936. 
Levy, J., Crawford, C., Hartmann, K., Hofmann-Lehmann, R., Little, S., Sundahl, E., \& Thayer, V. (2008). American Association of Feline Practitioners' Feline retrovirus management guidelines. Journal of Feline Medicine and Surgery, 10(3), 300-316. http://dx.doi.org/10.1016/j.jfms.2008.03.002. PMid:18455463.

Liem, B. P., Dhand, N. K., Pepper, A. E., Barrs, V. R., \& Beatty, J. A. (2013). Clinical findings and survival in cats naturally infected with feline immunodeficiency virus. Journal of Veterinary Internal Medicine, 27(4), 798805. http://dx.doi.org/10.1111/jvim.12120. PMid:23734699.

Little, S., Levy, J., Hartmann, K., Hofmann-Lehmann, R., Hosie, M., Olah, G., \& Denis, K. (2020). St. 2020 AAFP feline retrovirus testing and management guidelines. Journal of Feline Medicine and Surgery, 22(1), 5-30. http://dx.doi.org/10.1177/1098612X19895940. PMid:31916872.

Miyazawa, T., \& Jarrett, O. (1997). Feline leukaemia virus proviral DNA detected by polymerase chain reaction in antigenaemic but non-viraemic (discordant) cats. Archives of Virology, 142(2), 323-332. http://dx.doi.org/10.1007/ s007050050079. PMid:9125046.

Novo, S. G., Bucafusco, D., Diaz, L. M., \& Bratanich, A. C. (2016). Viral diagnostic criteria for feline immunodeficiency virus and feline leukemia virus infections in domestic cats from Buenos Aires, Argentina. Revista Argentina de Microbiologia, 48(4), 293-297. http://dx.doi.org/10.1016/j.ram.2016.07.003. PMid:27825735.

Poli, A., Tozon, N., Guidi, G., \& Pistello, M. (2012). Renal alterations in Feline Immunodeficiency Virus (FIV)infected cats: a natural model of lentivirus-induced renal disease changes. Viruses, 4(9), 1372-1389. http:// dx.doi.org/10.3390/v4091372. PMid:23170163.

Shelton, G. H., Linenberger, M. L., Grant, C. K., \& Abkowitz, J. L. (1990). Hematologic manifestations of feline immunodeficiency virus infection. Blood, 76(6), 1104-1109. http://dx.doi.org/10.1182/blood.V76.6.1104.1104. PMid:2400806.

Tasker, S., Murray, J. K., Knowles, T. G., \& Day, M. J. (2010). Coombs', haemoplasma and retrovírus testing in feline anaemia. The Journal of Small Animal Practice, 51(4), 192-199. http://dx.doi.org/10.1111/j.1748-5827.2009.00869.x. PMid:20070499.

Teixeira, B. M., Rajão, D. S., Haddad, J. P. A., Leite, R. C., \& Reis, J. K. P. (2007). Ocorrência do vírus da imunodeficiência felina e do vírus da leucemia felina em gatos domésticos mantidos em abrigos no município de Belo Horizonte. Arquivo Brasileiro de Medicina Veterinária e Zootecnia, 59(4), 939-942. http://dx.doi.org/10.1590/ S0102-09352007000400019.

Teixeira, B. M., Taniwaki, S. A., Menezes, P. M. M., Rodrigues, A. K. P. P., Mouta, A. N., Arcebispo, T. L. M., Braz, G. F., Cruz, J. C. M., Brandão, P. E., Heinemann, M. B., Silva, M. X., \& Hosie, M. J. (2019). Feline immunodeficiency virus in Northern Ceará, Brazil. Journal of Feline Medicine and Surgery Open Reports, 5(2), 1-7. http://dx.doi. org/10.1177/2055116919859112. PMid:31312511.

Turinelli, V., \& Gavazza, A. (2018). Retrospective study of 152 feline cytological bone marrow examinations: preliminary classification and ranges. Journal of Feline Medicine and Surgery, 20(12), 1158. http://dx.doi. org/10.1177/1098612X18757602. PMid:29451443.

Westman, M. E., Paul, A., Malik, R., McDonagh, P., Ward, M. P., Hall, E., \& Norris, J. M. (2016). Seroprevalence of feline immunodeficiency virus and feline leukaemia virus in Australia: risk factors for infection and geographical influences (2011-2013). Journal of Feline Medicine and Surgery, 2(1), 1-11. PMid:28491420. 